\title{
Variation in alien Lotus corniculatus L. 1. Morphological differences between alien and native British plants
}

\author{
Françoise Bonnemaison* \\ and David A. Jones
}

\author{
Department of Plant Biology and Genetics, \\ University of Hull, Hull HU6 7RX, England.
}

The native form of Lotus corniculatus $L$. in the north of Europe is a prostrate plant with small leaflets and short internodes. Morphologically different plants with erect growth habit, large leaflets, light keel petals and hollow stems have been introduced in the seed mixtures sown on new roadside verges. The alien plants are being studied to determine their persistance and the effect they may have on the adjacent native populations. Variation within and between two groups of alien plants growing near Hull has been measured. Discriminant analysis of 11 characters showing continuous variation gives a quantitative separation between the two groups of aliens, separates alien from native plants and can be used to detect hybrids between the two forms.

Le lotier spontané du nord de l'Europe est une plante généralement prostrée à petites feuilles et entre-noeuds courts. Des plantes morphologiquement différentes (port érigé, caréne pale, feuilles larges et tiges plus on moins creuses) ont été introduites lors du semis des remblais de routes nouvellement construites. L'étude de ces plantes introduites a pour objectif de déterminer leur persistance et l'effet de leur présence sur la population de plantes autochtones. Les plantes introduites sont comparées d'une part avec les plantes autochtones et d'autre part entre elles lorsqu'elles proviennent de sites différents prés de Hull. Une analyse discriminante sur onze caractéres biométriques a permis de quantifier la distance entre les groupes de plantes introduites, de mettre en évidence la présence d'hybrides entre autochtones et introduites.

\section{INTRODUCTION}

Research experience in the field of crop improvement has shown that whereas it is important to maintain as much genetic diversity as possible within existing varieties and older cultivars, it is vital to retain their wild relatives in as many habitats as possible. The artificial maintenance of diversity is, however, both difficult and expensive. An alternative approach is to monitor the genetic diversity of populations in natural habitats subjected to the rigours of natural selection. Roadside verges offer one semi-natural habitat which may prove to be ideal for this purpose. Roads traverse almost all types of terrain, their verges offer a complete spectrum of soil types at all altitudes and in all climates at which plants grow.

Legume seeds are a common constituent of the seed mixtures used for roadside verges (either by design or as contaminants), Lotus corniculatus L.

* Laboratoire génétique évolutive, B.P. 2, CNRS, Rte. de Mende BP5051, 34033 Montpellier, Cédex, France being one of these legumes. This species is of agricultural importance in Southern and Eastern Europe, U.S.A. (Seaney and Henson, 1970), Australia and New Zealand (Hoveland et al., 1982) where it is grown mainly as a fodder crop. In Northern Europe its use has been limited by a lack of persistence in dense grass sward and an inability to survive in persistently wet soils. Lotus uliginosus Schkuhr. replaces $L$. corniculatus under these latter conditions. L. corniculatus is, nonetheless, a good coloniser of very poor quality soils and, as heavy metal tolerant plants are available (Glen and Jones, unpublished observations), this species may be particularly useful as a primary coloniser of derelict wasteland and in the improvement of upland pastures. Moreover, being a legume, it has the ability to improve the nutrient level of arable soils.

Native plants of L. corniculatus in Northern Europe are prostrate, with short internodes and small leaflets. Alien strains, recognisable by their erect growth habit have been recorded from U.K., 
West Germany, Denmark and the Netherlands (Jones, 1973a) alongside new roads or recently modified roads. These alien forms are almost invariably cyanogenic, with large leaflets and light keel petals. Jones (1973b) has suggested that upright growth habit is dominant.

Using these alien plants we have begun the study of some problems of ecological genetics, conservation and management. For example:

1. To what extent do the aliens outcross with native plants?

2. Are the aliens persistent?

3. Although aliens obtained from different locations appear to be similar when grown in the glasshouse, are they physiologically and morphologically distinct?

4. Are the aliens found in the roadside populations produced from a random sample of seeds in the seed mixture or have the habitats exerted strong selection on the seedlings?

5. What is the origin of these aliens?

6. Are these aliens growing in roadside verges in Northern Europe a good source of the heritable variation required for establishing the species among the agronomically important plants of Northern Europe and North America?

Furthermore, L. corniculatus forms colonies and so we are also in the unusual position of being able to study the colonising process from the beginning. Although the aliens are very distinct, the first stage in this study was to use a number of morphological characters to obtain a quantitative estimate of the differences between native and alien plants and between aliens growing in different environmental conditions. This should then allow us to detect hybrid plants if and when they appear in natural populations.

\section{MATERIALS AND METHODS}

\section{(i) Field observations}

Alien plants of Lotus corniculatus are established in two roadside habitats near to Hull. One is near the village of Etton (SE 990436) on the B1248 road. Roadworks were completed in 1980 and the aliens were first noticed in the summer of 1981. At this site alien and native plants occur on both sides of the road over a stretch of approximately $200 \mathrm{~m}$, but the two types are neither evenly nor randomly distributed. The second site is beside the M180 motorway (SE 944066) near Scawby. The road was constructed as a cutting through well established woodland and the virgin soil was textured with
"Alginure" $\dagger$ at the time of seeding, early in 1981 There are no native plants within $400 \mathrm{~m}$ of the site and the aliens are associated with Trifolium repens L., Trifolium pratense L. and Lotus uliginosus. $L$. corniculatus is confined to the drier southern verge.

At Etton 23 native plants and 27 aliens were labelled, whereas at Scawby 30 plants have been marked. Each label was attached to a length of green steel wire placed around the crown of the plant. At Etton it was difficult to classify seven plants unambiguously as alien or native. Each plant was assigned to the more suitable category, however, based on whether the plant appeared more alien or more native. Several morphological characters were recorded directly from these plants in situ while others were measured in the laboratory (table 1). Ten flowers and ten leaves were collected from each plant. The leaves chosen were those subtending the first branch behind the stem apex so that true comparisons could be made between leaves on the same plant and between plants. The area of each leaf and of the standard petal was measured using a Lambda LI-3000 Area Meter and the length of the keel petals was also recorded (fig. 1). Later in the season, ten ripe pods were collected from each plant and the length (undehisced) and the number of seeds per pod were recorded. Each plant was tested for

Table 1 Summary of characters studied

\begin{tabular}{|c|c|}
\hline Stem & $\begin{array}{ll}* & \text { hollow }(11), \text { intermediate }(01), \text { solid }(00) \\
* & \text { hairy }(11), \text { sparsely hairy }(01) \text {, glabrous }(00) \\
* & \text { length }(\mathrm{cm}) \\
* & \text { diameter }(\mathrm{cm})\end{array}$ \\
\hline Branches & $\begin{array}{l}\text { * number of primary branches per main stem } \\
\text { number per } \mathrm{cm}\end{array}$ \\
\hline Internode & * length $(\mathrm{cm})$ \\
\hline Leaf & $\begin{array}{l}\text { * hairy }(11), \text { sparsely hairy }(01), \text { glabrous }(00) \\
\text { cyanogenic (1), acyanogenic }(2) \\
\text { area }\left(\mathrm{cm}^{2}\right)\end{array}$ \\
\hline Calyx & * hairy (11), sparsely hairy $(01)$, glabrous $(00)$ \\
\hline Keel & $\begin{array}{l}\text { * dark }(1), \text { light }(2) \\
\text { length }(\mathrm{cm})\end{array}$ \\
\hline Standard & area $\left(\mathrm{cm}^{2}\right)$ \\
\hline Pod & $\begin{array}{l}\text { length }(\mathrm{cm}) \\
\text { number per umbel }\end{array}$ \\
\hline Seed & number per pod \\
\hline
\end{tabular}

* These characters were recorded from plants in situ. The other characters were scored on material brought back to the laboratory

$\dagger$ Registered trade mark of COMTEC (UK) Ltd. 


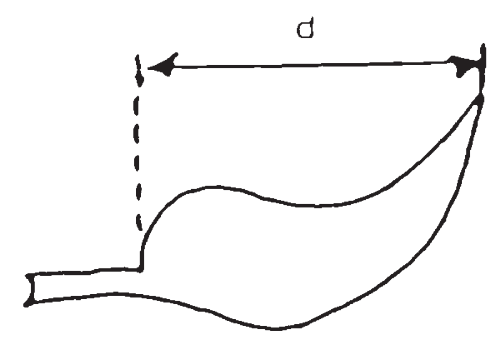

$d=$ keel petal length

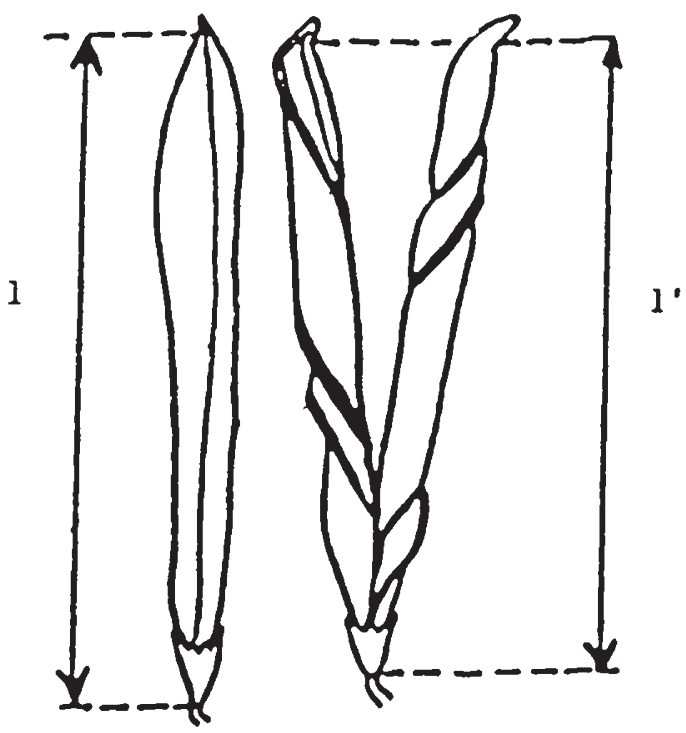

$$
\begin{aligned}
& l=1^{\prime}+0.06 \mathrm{~cm} \\
& 1=\text { pod length }
\end{aligned}
$$

Figure 1 The characters of keel petal length and pod length. When the pod dehisces the valves twist violently and so shorten. Because some pods had dehisced before they could be measured it was necessary to determine the relationship between the length of an undehisced pod and the same pod after dehiscence. Examination of a number of pods showed that the twisting reduced the length by an average of $0.06 \mathrm{~cm}$. The measured length of a dehisced pod was therefore increased by $0.06 \mathrm{~cm}$ to obtain its predehisced length.

cyanogenesis using the Feigl-Anger test (1966) as modified by Tantisewie et al. (1969).

\section{(ii) Chromosomes}

The alien plants frequently have hollow stems, corresponding to var. sativa of Chrtková-Žertová (1973). As hollow stems are characteristic of Lotus uliginosus there is clearly some confusion possible between hollow stemmed L. corniculatus and L. uliginosus. Fortunately L.uliginosus has 12 chromosomes and $L$. corniculatus 24 . Thus it was thought sensible to examine the root-tip chromosomes of some of the alien plants.

Cuttings were taken from all the labelled plants and rooted in the mist unit in peat and sand. The small plants were transplanted into John Innes No. 2 compost in $24 \mathrm{~cm}$ plastic pots and placed in the cool glasshouse. Root tips were collected from 10 Etton and 10 Scawby aliens and treated with 8hydroxyquinoline $(0.002 \mathrm{M}$ ) (Zandstra and Grant, 1968). Root-tips were fixed in 3:1 ethanol-glacial acetic acid, hydrolised in $5 \mathrm{~N} \mathrm{HCl}$ and stained in lacto-propionic orcein (Dyer, 1979 after Darlington and La Cour, 1969).

\section{(iii) Analysis}

The aim of the study was to distinguish quantitatively between the two groups of plants, alien and native. The plants can be separated by eye on the basis of their gross characteristics, but we wanted to know which morphological characters would give us the best separation between the groups and also to quantify these distinguishing features. Discriminant function analysis provides one means of obtaining this information. The uses of this technique have been described by Mardia et al. (1979) and Green (1978) and the application to ecological investigations has been reviewed by Williams (1983).

Discriminant analysis can be used for two purposes-allocation of additional members to an existing classification and for analysis of an a priori classification. The first of these has been employed extensively in medical studies (Healy, 1965); Romeder, 1978). Ecological application of the second technique includes analyses of the differences between some beechwood ground floras (Norris and Barkham, 1970), studies of the variability within and between four types of woodland in oak/hickory forest (Grigal and Goldstein, 1971), and for analysing the variability of some successional plant assemblages (Matthews, 1979). Baum and Bailey (1983a, b) used a combination of the two methods to establish the validity of different taxonomic entities of Hordeum vulgare L. and to classify hybrids among the groups they had established.

For this study we employed a stepwise discriminant function analysis programme (SPSS, version 9, Nie et al., 1975) both to separate native and alien plants and to classify additional 
individuals which could not be allocated into one of these a priori groups. At each step of the analysis a new variable is introduced into a linear combination of variables, the variable entered being that which provides the best maximisation of the discrimination obtained at the preceding step. At each step it is also possible to remove a variable if its discriminant power has become redundant. Thus when two variables provide the same kind of information only one will be taken into the discriminant function.

Covariance analysis and the investigation of the best discriminant function (best combination of the variables) are based on the quality of the representation of data in canonical space. For statistical inference we have to apply a very restrictive probabilistic hypothesis that is seldom respected in reality, (e.g., multinormal distribution of the observations in a group around the centroids, equality of the variance-covariance matrix within the group, independence between measurements of the same character on different plants). For these reasons care must be taken when drawing conclusions from the test, with more account being taken of the geometrical representation of the separation of the groups than of the statistical significance obtained.

\section{RESULTS}

\section{(i) Chromosomes}

All the alien plants from Etton and Scawby had 24 chromosomes, confirming that they were $L$. corniculatus and not L. uliginosus. Additionally, some previously collected plants of $L$. uliginosus and of both native and alien plants from Etton were examined and confirmed the distinction between the two species.

\section{(ii) Qualitative characters}

Because continuous and discontinuous variables do not have the same properties when represented in a mathematical continuous space, qualitative and quantitative variables were analysed separately. Table 2 shows the number of the plants in the different morphological character groups. The differences between the three groups of plants are obvious and analysis is scarcely necessary.

Leaf cyanogenesis in this part of England has been described by Jones (1977) and Jones and Crawford (1977) and wild populations have a high percentage of cyanogenic plants. It seems that
Table 2 Number of plants of each phenotype among the three groups of plants at Etton and Scawby

\begin{tabular}{|c|c|c|c|c|}
\hline & & $\begin{array}{l}\text { Natives } \\
\text { at Etton }\end{array}$ & $\begin{array}{l}\text { Aliens } \\
\text { at Etton }\end{array}$ & $\begin{array}{l}\text { Aliens } \\
\text { at Scawby }\end{array}$ \\
\hline $\begin{array}{l}\text { Leaf } \\
\text { cyanogenesis }\end{array}$ & $\begin{array}{l}\text { cyanogenic } \\
\text { acyanogenic } \\
\% \\
\text { acyanogenic }\end{array}$ & $\begin{array}{r}23 \\
0 \\
0\end{array}$ & $\begin{array}{l}26 \\
1 \\
3 \cdot 7\end{array}$ & $\begin{array}{l}28 \\
2 \\
6 \cdot 7\end{array}$ \\
\hline Keel colour & $\begin{array}{l}\text { light } \\
\text { dark }\end{array}$ & $\begin{array}{r}2 \\
21\end{array}$ & $\begin{array}{r}26 \\
1\end{array}$ & $\begin{array}{r}30 \\
0\end{array}$ \\
\hline Stem & $\begin{array}{l}\text { hollow } \\
\text { solid }\end{array}$ & $\begin{array}{r}9 \\
14\end{array}$ & $\begin{array}{r}24 \\
3\end{array}$ & $\begin{array}{r}30 \\
0\end{array}$ \\
\hline \multicolumn{5}{|l|}{ Hairyness } \\
\hline leaves & $\begin{array}{l}\text { absent } \\
\text { sparse* } \\
\text { abundant } \\
\text { absent }\end{array}$ & $\left.\begin{array}{c}1 \\
13 \\
9 \\
2\end{array}\right\} 22$ & $\left.\begin{array}{c}23 \\
4 \\
0\end{array}\right\} 4$ & $\left.\begin{array}{c}25 \\
4 \\
0 \\
28\end{array}\right\} 4$ \\
\hline stem & $\begin{array}{l}\text { sparse } \dagger \\
\text { abundant } \\
\text { absent }\end{array}$ & $\left.\begin{array}{c}21 \\
0\end{array}\right\} 21$ & $\left.\begin{array}{r}3 \\
0\end{array}\right\} 3$ & $\left.\begin{array}{l}1 \\
0 \\
8\end{array}\right\} 1$ \\
\hline calyx & $\begin{array}{l}\text { sparse } \ddagger \\
\text { abundant }\end{array}$ & $\left.\begin{array}{r}23 \\
0\end{array}\right\} 23$ & $\left.\begin{array}{r}11 \\
0\end{array}\right\} 11$ & $\left.\begin{array}{r}19 \\
2\end{array}\right\} 21$ \\
\hline
\end{tabular}

\footnotetext{
* Hairs only along the central rib

$\dagger$ Few hairs along the stem

$\ddagger$ Hairs only along the teeth
}

cyanogenesis in Lotus corniculatus varieties is associated with morphological characters of agronomic importance, (Jones, 1977; Blaim and Nowacki, 1979). Thus it is not surprising to find that the percentage of acyanogenic plants among the aliens is only 3.7 at Etton and 6.7 at Scawby and that there are no native acyanogenic plants at Etton. For the keel petal colour the majority of aliens have light keels, whereas the native forms are almost all dark keeled. Polymorphism in the keel colour in Western Europe has been studied by Jones and Crawford (1977) who have found the dark keeled phenotype to be more frequent in this part of England. Solid stem appears to be a characteristic of the native form in contrast with the hollow stem frequently found among the aliens. Hairiness is not such a discriminating character between alien and native forms, but at least for the leaves we can say that the native form is hairier than the alien.

\section{(iii) Discrimination between groups}

The means and standard deviations of the quantitative variables (table 3 ) show great differences between the three groups. There is "gigantism" of the alien plants compared with the native form for all vegetative characters. On the contrary, the 
Table 3 Means and standard deviations of the quantitative morphological characters for each group

\begin{tabular}{|c|c|c|c|c|c|c|}
\hline & Natives & & $\begin{array}{l}\text { Aliens } \\
\text { from Etton }\end{array}$ & & $\begin{array}{l}\text { Aliens } \\
\text { from Scawby }\end{array}$ & \\
\hline & Mean & $\begin{array}{l}\text { Standard } \\
\text { deviation }\end{array}$ & Mean & $\begin{array}{l}\text { Standard } \\
\text { deviation }\end{array}$ & Mean & $\begin{array}{l}\text { Standard } \\
\text { deviation }\end{array}$ \\
\hline Maximum stem length $(\mathrm{cm})$ & $27 \cdot 12$ & $7 \cdot 66$ & $60 \cdot 33$ & $12 \cdot 95$ & $106 \cdot 19^{*}$ & $122 \cdot 22$ \\
\hline Flowers/umbel & 3.60 & 0.42 & $5 \cdot 35$ & 0.87 & $4 \cdot 79$ & 1.08 \\
\hline Branches/stem & $4 \cdot 83$ & 0.73 & $5 \cdot 29$ & 1.68 & $7 \cdot 54$ & $2 \cdot 66$ \\
\hline Leaf area $\left(\mathrm{cm}^{2}\right)$ & 1.43 & 0.33 & $3 \cdot 50$ & 0.96 & $5 \cdot 22$ & $1 \cdot 13$ \\
\hline Standard area $\left(\mathrm{cm}^{2}\right)$ & 0.77 & 0.06 & 0.69 & $0 \cdot 12$ & 0.72 & $0 \cdot 11$ \\
\hline Keel length $(\mathrm{cm})$ & 0.88 & 0.08 & 0.76 & 0.06 & 0.75 & 0.05 \\
\hline Stem diameter $(\mathrm{cm})$ & $0 \cdot 14$ & 0.01 & $0 \cdot 22$ & 0.02 & 0.22 & 0.03 \\
\hline Pods/umbel & $2 \cdot 61$ & 0.61 & $3 \cdot 87$ & 0.94 & 3.61 & 0.75 \\
\hline Seeds/pod & 10.73 & 2.95 & $15 \cdot 62$ & 5.06 & $11 \cdot 53$ & $5 \cdot 20$ \\
\hline
\end{tabular}

* The length of stems at Scawby was highly variable

flower (e.g., standard and keel petals) is much more developed in the native form than in the alien. It is interesting that for a very little difference in pod size, the aliens at Etton have a greater seed yield per pod than the natives $(0 \cdot 01>P>0.001)$.

Three discriminant analyses have been done, one to separate the two forms growing together at Etton, the second to look at the differences between the two groups of aliens while the third is a combined analysis of the three groups.

As mentioned previously the stepwise analysis adds the variables to the discriminant function one by one. The inclusion sequences of the variables are given in table 4.

The discriminating power of the variables differs with the analysis. In the analysis between

Table 4 Inclusion sequence of the variables in the discriminant function

\begin{tabular}{|c|c|c|c|c|}
\hline & Step & Variables entered & \multicolumn{2}{|c|}{$\begin{array}{l}\text { Standardised canonical } \\
\text { discriminant function coefficient }\end{array}$} \\
\hline a) & 1 & Internode length & \multicolumn{2}{|c|}{0.531} \\
\hline Discrimination & 2 & Seed/pod & \multicolumn{2}{|c|}{0.871} \\
\hline between & 3 & Stem diameter & \multicolumn{2}{|c|}{0.839} \\
\hline aliens and & 4 & Keel length & \multicolumn{2}{|c|}{-0.431} \\
\hline natives at & 5 & Branches/stem & \multicolumn{2}{|c|}{$-0 \cdot 325$} \\
\hline Etton & 6 & Pod length & \multicolumn{2}{|c|}{-0.329} \\
\hline b) & 1 & Leaf area & \multicolumn{2}{|c|}{$0 \cdot 602$} \\
\hline Discrimination & 2 & Branches/stem & \multicolumn{2}{|c|}{0.551} \\
\hline between & 3 & Flower/umbel & \multicolumn{2}{|c|}{$-0 \cdot 320$} \\
\hline aliens from & 4 & Keel length & \multicolumn{2}{|c|}{-0.480} \\
\hline two different & 5 & Stem diameter & \multicolumn{2}{|c|}{0.491} \\
\hline locations & 6 & Internode length & \multicolumn{2}{|c|}{-0.453} \\
\hline & 7 & Stem length & \multicolumn{2}{|c|}{$0 \cdot 287$} \\
\hline & & & Function 1 & Function 2 \\
\hline c) & 1 & Leaf area & $0 \cdot 271$ & -0.551 \\
\hline Discrimination & 2 & Branches/stem & $0 \cdot 171$ & -0.457 \\
\hline between the & 3 & Flower/umbel & -0.041 & $0 \cdot 338$ \\
\hline \multirow[t]{8}{*}{ three groups } & 4 & Stem diameter & \multirow[t]{2}{*}{0.597} & \multirow[t]{2}{*}{-0.137} \\
\hline & 5 & Standard area & & \\
\hline & 6 & Internode length & 0.413 & 0.719 \\
\hline & 7 & Stem length & -0.004 & $-0 \cdot 312$ \\
\hline & 8 & Seed/pod & 0.677 & 0.681 \\
\hline & 9 & Keel length & \multirow[t]{2}{*}{-0.487} & \multirow[t]{2}{*}{$0 \cdot 124$} \\
\hline & 10 & Standard area (removed) & & \\
\hline & 11 & Pod length & -0.364 & $-0 \cdot 341$ \\
\hline
\end{tabular}


aliens and in the analysis between the three groups we obtained nearly the same sequence. It is easier to separate the natives from the aliens than to separate the two groups of aliens, so that when all three groups are examined together the analysis emphasised the difference between the aliens thereby giving rise to the similar sequences. We must point out here the importance of the correlations between variables; for instance, the area of the standard petal and length of the keel petal are strongly correlated $\left(r_{(63)}=0.65,0.01>P>0.001\right)$ and the addition of keel length in the function leads to the exclusion of the area of the standard petal after the next step. In further studies we can use these results to choose which of the characters we have measured should be included and which ones we can ignore. Standardised canonical discriminant function coefficients show the relative contribution of each variable in the function at the end of the analysis.

Seeds per pod and stem diameter are the variables which give the greatest contribution to the function separating aliens and natives. Leaf area and branches per stem are the most important in the separation of the two aliens.

In the analysis of the three groups together we obtain the combination of both the previous analyses and of the variables. The most important are: seeds per pod, stem diameter in the first function and internode length, seeds per pod and leaf area in the second function.

\section{(iv) Graphical separation of the groups}

All plants were correctly classified by the discriminant function separating alien and native plants. Fig. 2 shows the histogram of the frequency of plants plotted against the function. To each plant a discriminant score is attributed in relation to the values of each variable included in the function. There is no overlap at all between the two histograms, but during our observations we found it difficult to classify seven plants into one of the two groups. These plants have some characters more alien and others more native. After computing the discriminant scores on the basis of the discriminant function established with the plants classified $a$ priori, the unclassified plants have been allocated to one of the two groups. It was possible to identify where these ambiguous plants were located in the histogram. Two of them have been classified in the native group, the five others are exactly between the two groups (fig. 2 and fig. 4).

Because we have chosen two extreme categories-alien and native-to obtain the dis-

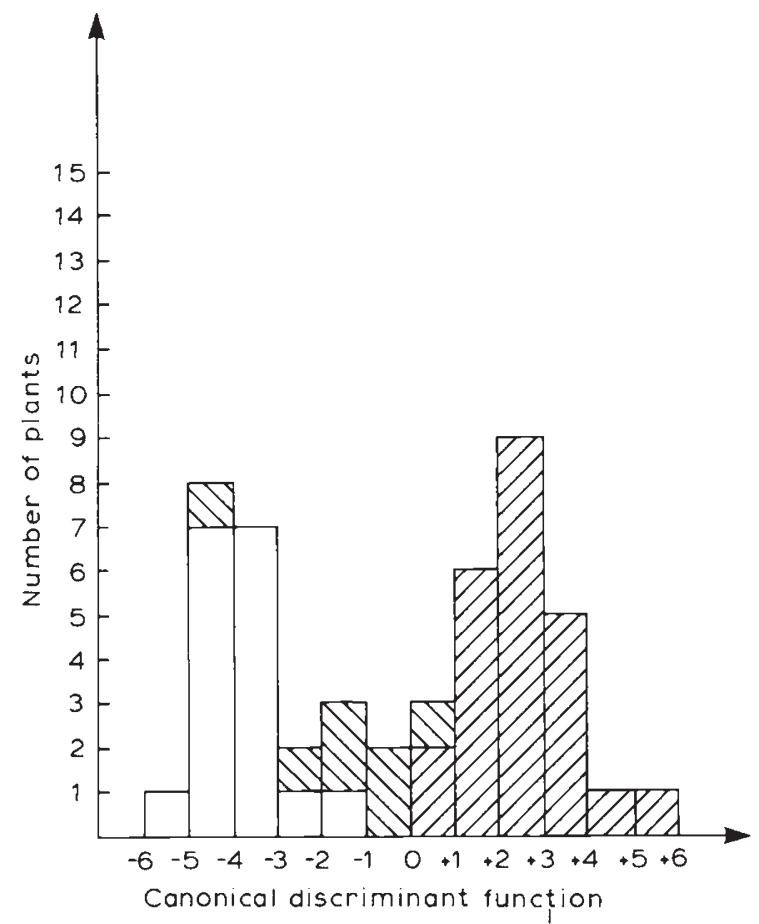

Figure 2 Native and alien groups at Etton. $\square$ Native, $\mathbb{Z}$ alien, Sdifficult to classify a priori. Two plants were excluded from the analysis because each had at least one missing discriminating variable.

criminant function it is not surprising to find that the indeterminate plants are intermediate. On the other hand, because the analysis shows that two of the indeterminate plants can be classified with the natives we have been able to use the the technique for both the analysis of an a priori classification and for allocation of additional members to an existing classification.

The five plants placed exactly between the two groups (fig. 2 and fig. 4) are likely to be hybrids and so it appears that this type of analysis will enable us to follow the interbreeding of aliens and natives and thence of introgression.

For separating the two groups of alien plants 88.4 per cent of the plants were correctly classified by the discriminant analysis. The histograms (fig. 3) for the two groups are overlapping, but the mode of each one is very distinct.

Fig. 4 is the visualisation of the results of the analysis using all the three groups. The first function differentiates the two aliens while the second serves to distinguish aliens and natives. This representation shows the relative distance between groups. The analysis includes Mahalanobis's distance $D^{2}$ statistic (fig. 4). This method seeks to maximise the Mahalanobis distance between the 


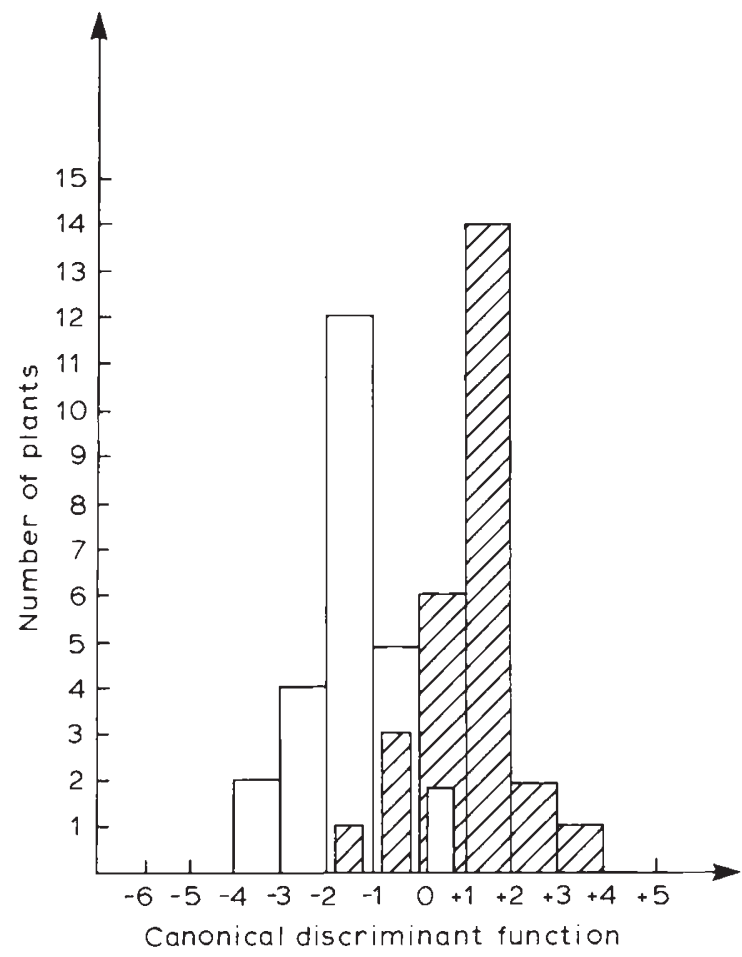

Figure 3 Two alien groups. $\square$ Alien from Etton, $\mathbb{Z}$ alien from Scawby. Five plants were excluded from the analysis because each had at least one missing discriminating variable.

two closest groups. From this figure we can easily see that the distance between aliens and natives is much larger when they are growing in different locations, while the distance between aliens is much smaller than the distance between aliens and natives.

\section{DISCUSSION}

We have compared various morphological characters of alien and native plants of Lotus corniculatus and found that the differences can be quantified. The separation of the two groups is very clear and should enable us to detect hybrids between the natives and aliens as and when they occur.

The discrimination between the two groups of aliens growing in different sites is less obvious. Although it is likely that these aliens are cultivars whose seeds were included in the seed mixtures used to sow the verges of new roads, at this stage of the study we are not able to identify the cultivars.

Lotus corniculatus is well known as a highly variable species, probably because it is tetraploid (e.g., Stebbins, 1950), and is very troublesome taxonomically (Chrtková-Žertová, 1973; Small et al., 1984). The presence of cultivars in "seminatural" habitats complicates the issue further. Chrtková-Žertová (1973) argues, we believe correctly, that the variability of $L$. corniculatus has enabled the species to move into a large number of different habitats and so today it is distributed over a very wide area. She records 14 varieties in Europe and certainly there is considerable overlap between these varieties. For this reason we need to compare our two groups of aliens when they are growing in the same environmental conditions and stocks have now been established in the glasshouse. We must examine the phenotypes of known hybrids between the native and alien plants at Etton and, furthermore, we should check that the variation within alien populations and between populations has an heritable basis. Work to this end is also under way.

A pilot study on herbarium specimens (Dearnley, 1983) showed that the material was unsatisfactory for our purpose because several of the characters that we wished to observe or measure were damaged or distorted by drying. Leaf area, standard petal area, cyanogenesis and hollow stem cannot be measured satisfactorily on preserved material. By using living material and labelling the plants in the field it was possible to make replicate measurements and to look at flowers and fruits on the same plant. Thus we were able to include a much larger array of characters than is usually possible with herbarium specimens. Small et al. (1984) deliberately confined their studies to those characters traditionally used by herbariumbased taxonomists whereas we chose an array of characters looking for those that would help us most readily to distinguish between natives and aliens and to recognise hybrids.

With Lotus corniculatus we have three genetic polymorphisms that we can use as markers: leaf cyanogenesis, petal cyanogenesis and keel petal colour. The distribution of leaf cyanogenesis (Jones, 1977) and of keel colour (Jones and Crawford, 1977; Abbott, 1981) in western Europe are reasonably well known and evidence on the petal cyanogenesis is accumulating (Jones, 1977; Compton et al., 1983). Of these only the keel colour polymorphism will be of any use at Etton and then only by rearing to the flowering stage seeds obtained from alien plants. Obviously allozyme polymorphisms would be a useful addition to the range of markers that could be used for identifying and distinguishing plants and some progress to this end has been made in our laboratory (Beesley, personal communication). 


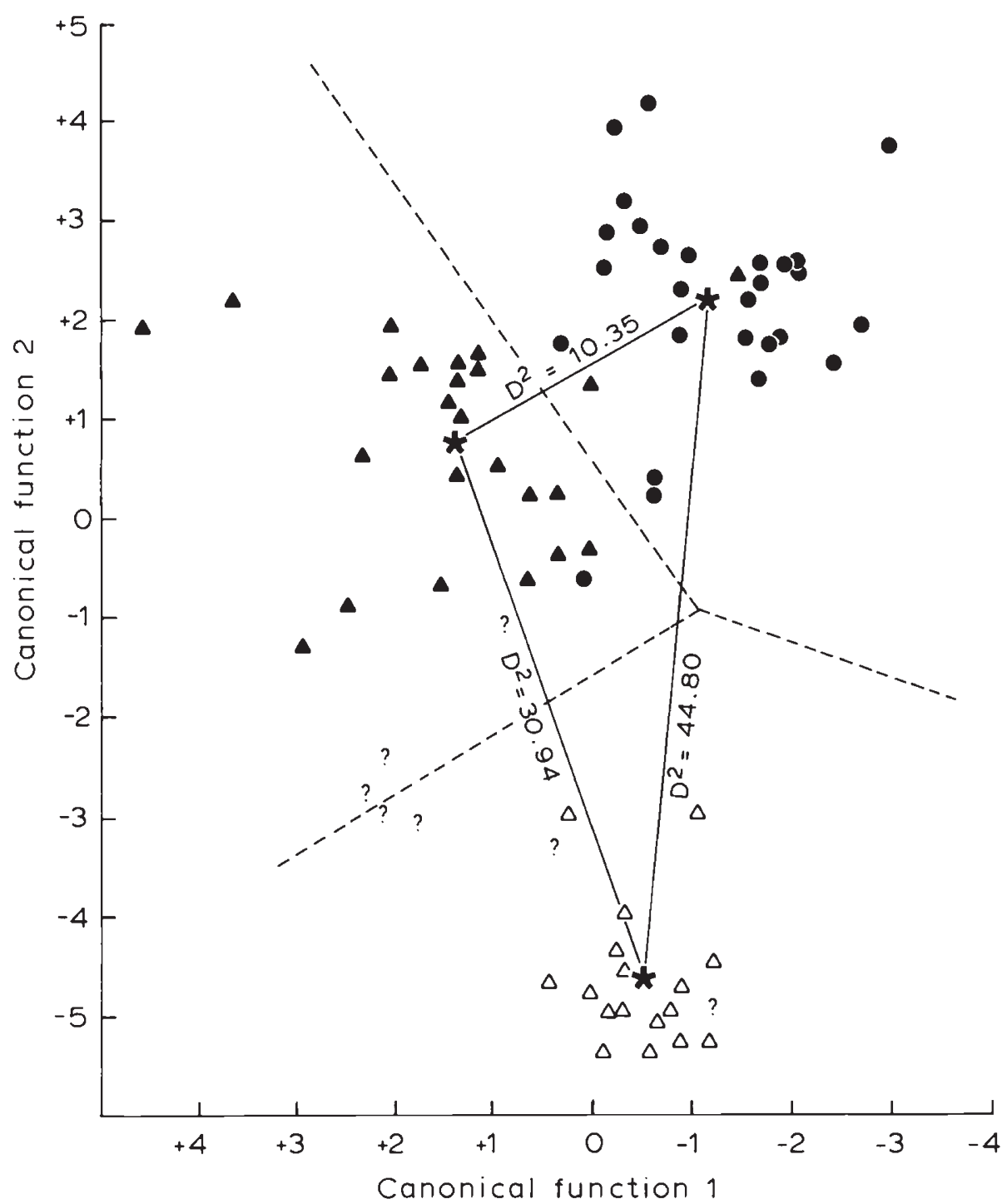

Figure 4 Plot of first two canonical functions. $\triangle$ Native plants from Etton, $\Delta$ alien plants from Etton, $\bigcirc$ alien plants from Scawby, ? ungrouped plants from Etton, $\boldsymbol{k}$ centroids and $D^{2}$ Mahalanobis's distance.

The leaf cyanogenesis polymorphism has been used as a marker in the study of alien L. corniculatus in Denmark (Jones, 1973b). The aliens were introduced at Sundstrup in the summer of 1967 and it is known that alien plants were still growing there in 1979 (Compton, personal communication). The aliens first observed on the Clent Hills near Birmingham in 1970 (Jones, 1977) were well established in the summer of 1983. There is good evidence, therefore, that the aliens are persistent in some locations although the aliens growing beside the A40 road at Monmouth (Jones, 1977) in 1982 could not be found in 1983.
The deliberate transfer of plants and animals to study their genetic response is by no means a new technique. It was the basis of the work of Clausen and Hiesey (1958) with Potentilla glandulosa Lindl. They employed both reciprocal transplant techniques and transplantation into the experimental garden. Our experience with $L$. corniculatus is, however, more directly comparable with the work of Sheppard (1951) and Sheppard and Cook (1962) who introduced the medionigra form of Panaxia dominula L. into the monomorphic (dominula) population at Sheepstead Hurst and then founded a new population, including 
medionigra, at Hinksey. As a result they obtained considerable insight into the selection acting on the dominula/medionigra/bimacula polymorphism of $P$. dominula. At Etton the aliens have been added to an existing population of $L$. corniculatus whereas at Scawby a new population, entirely of aliens, has been founded. We are continuing to look for other populations of alien Lotus corniculatus both with and without natives so that we can make comparison between our Etton and Scawby results and what happens elsewhere.

There is no doubt that the alien plants both at Etton and at Scawby have morphological characters suitable for agronomic purposes: large leaflets, long stems, erect habit. The agronomic potential of the species in the U.K. has been advocated for many years (e.g., Ellis, 1743; Robinson, 1934), but it is only in the U.S.A. and Canada that any significant progress has been made (McDonald, 1946; Poostchi and MacDonald, 1961; Fay et al., 1980; Lees et al., 1981). Indeed, Grant and Marten (1984) have evidence that $L$. corniculatus is now second only to Medicago sativa $\mathrm{L}$. in importance as a forage legume in North America. Our studies of the establishment, persistance and general biology of the aliens at Etton and Scawby will allow us to estimate their potential for agronomic use in eastern England.

The occurrence of readily recognisable aliens of $L$. corniculatus in the roadside verges of most of the countries in north west Europe suggests that the extensive distribution of alien forms of common species all over Europe has been a continuous process since the building of new roads on a large scale began shortly after 1945 . L. corniculatus would be only an indicator of this process, detailed analysis of the species and varieties of the grasses being necessary to establish the fact of any particular situation. We are used to large scale importation of seeds of agricultural crops (e.g., wheat, barley), of horticultural crops (e.g., brussels sprouts, cucumbers) and of a large number of species of garden plants-particularly by more ambitious seed merchants-but as most of these are not native species escapes do not fare particularly well (Salisbury, 1961). Alien plants are also frequently found in dockland areas, but rarely are capable of spreading far away from the initial site. With roadside verges, however, aliens forms of common species are being sown as components of seed mixtures. It is probably largely accidental when alien material is used-merely reflecting what seed is available commercially at the time. Furthermore, it is very unlikely that a seed merchant could supply for roads, say in Norfolk, seeds of Lolium perenne L., Festuca rubra L., Poa pratensis L., Phlem pratense L. or Cynosurus cristatus L. derived from Norfolk sources.

Two recent publications (Parsons, 1983; Evered and Collins, 1984) expose our lack of understanding of the colonising process and of the origin of new variation in natural populations. While recognising the ethical problems raised by the large scale introduction of alien plants in seed mixtures, this practice nevertheless provides an opportunity for studying the colonising process of alien plants in natural populations right from the beginning.

Acknowledgments We are grateful to S. G. Compton for his help and interest while the work was in progress and to $G$. Caraux for his advice on statistical matters. We also thank Ms V. Fairhurst for her technical assistance.

F. Bonnemaison was supported by a grant from Le Ministére de l'Industrie et de la Recherche, Paris, France.

\section{REFERENCES}

АввотT, R. J. 1981. The keel petal colour polymorphism of Lotus corniculatus in Scotland. New Phytol., 88, 549-553.

BAUM, B. R. AND BAILEY, L. G. 1983a. Morphometric relationships in Hordeum vulgare (Triticeae, Poaceae). I. H. spontaneum. Can. J. Bot., 61, 2015-2022.

BAUM, B. R. AND BAILEY, L. G. 1983b. Morphometric relationships in Hordeum vulgare (Triticeae, Poaceae). II. Hordeum agriocrithon, $H$. distichum, $H$. lagunculiforme, $H$. spontaneum and $H$. vulgare. Can. J. Bot., 61, 2023-2031.

BLAIM, H. AND NOWACKI, E. 1979. Cyanogenesis in Lotus and Trifolium species. Acta agrobotanica, 32, 19-26.

CHRTKOVÁ-ŽERTOVÁ, A. 1973. A monographic study of Lotus corniculatus L. I. Central and Northern Europe. Rozpravy Československé Akademie Věd, 83, 1-94.

CLAUSEN, J. AND HIESEY, W. M. 1958. Experimental studies on the nature of species IV. Genetic structure of ecological races. Carnegie Institution of Washington Publication, 615, 1-312.

COMPTON, S. G., NEWSOME, D. AND JONES, D. A. 1983. Selection for cyanogenesis in the leaves and petals of Lotus corniculatus L. at high latitudes. Oecologia, 60, 353-358.

DARLINGTON, C. D. AND LA COUR, L. A. 1969. The handling of chromosomes, (5th ed.). George Allen and Unwin, London.

DEARNLEY, S. E. 1983. Morphological variation in European Lotus corniculatus. Unpublished BSc Project Report, University of Hull.

DYER, A. F. 1979. Investigating chromosomes, Edward Arnold, London.

ELLIS, w. 1743. The modern husbandman: or, the practice of farming, (pp. 70-72, May issue). George Faulkner, Dublin.

EVERED, D. AND COLLINS, G. N. eds 1984. Origins and development of adaptation. Pitman (for the C.I.B.A. Foundation), London.

FAY, J. P., CHENG, K.-J., HANNA, M. R., HOWARTH, R. E. AND COSTERTON, J. W. 1980 . In vitro digestion of bloat-safe and bloat-causing legumes by rumen microorganisms: Gas and foam production. J. Dairy Sci., 63, 1273-1281. 
FEIGL, F. AND ANGER, V. 1966. Replacement of benzidine by copper ethylacetoacetate and tetrabase as spot-test reagent for hydrogen cyanide and cyanogen. Analyst, 91, 282-284.

GRANT, W. F. AND MARTEN, G. C. 1984. Birds-foot trefoil. In Heath, M. E., Metcalfe, D. S. and Bomes, R. S. (eds.), Forages: the science of grassland agriculture. Iowa State University Press, Ames.

GRIGAL, D. F. AND GOLDSTEIN, R. A. 1971. An integrated ordination classification analysis of an intensively sampled oak-hickory forest. Journal of Ecology, 59, 481-492.

GREEN, P. E. 1978. Analyzing multivariate data. The Dryden Press, Hinsdale, Illinois.

HEALY, M. J. R. 1965. Descriptive uses of discriminant functions. In Mathematics and Computer Science in Biology and Medicine (ed. for the Medical Research Council). H.M.S.O., London, pp. 93-102.

HOVELAND, C. S., HAALAND, R. L., HARRIS, R. R. AND MCGUIRE, J. A. 1982. Birdsfoot trefoil in Alabama. Alabama Agricultural Experiment Station Bulletin, 537, $1-16$.

JONES, D. A. 1973a. Co-evolution and cyanogenesis. In Heywood, V. H. (ed.), Taxonomy and Ecology. Academic Press, London, pp. 213-242.

JONES, D. A. 1973b. On the polymorphism of cyanogenesis in Lotus corniculatus L. V. Denmark. Heredity, 30, 381-386.

JONES, D. A. 1977. On the polymorphism of cyanogenesis in Lotus corniculatus L. VII. The distribution of the cyanogenic form in Western Europe. Heredity, 39, 27-44.

JONES, D. A. AND CRAWFORD, T. J. 1977. Variation in the colour of the keel petals in Lotus corniculatus L. I. The polymorphism in Western Europe. Heredity, 39, 313-325.

LEES, G. L., HOWARTH, R. E., GOPLEN, B. P. AND FESSER, A. C. 1981. Mechanical disruption of leaf tissues and cells in some bloat-causing and bloat-safe forage legumes. Crop Sci., 21, 444-448.

MARDIA, K. V., KENT, J. T. AND BIBBY, J. M. 1979. Multivariate analysis. Academic Press, New York.

MATHEWS, J. A. 1979. A study of the variability of some successional and climax plant assemblage-types using multiple discriminant analysis. J. Ecol., 67, 255-271.

MACDONALD, H. A. 1946. Birdsfoot trefoil (Lotus corniculatus L.) Its characteristics and potentialities as a forage legume.
Cornell University Agricultural Experiment Station Memoir, 261, 1-182.

NIE, N. H., HULL, C. H., JENKINS, J. G., STEINBRENNER, K. AND BENT, D. H. 1975. Statistical package for the social sciences, (2nd ed.). McGraw Hill, New York, pp. 434-467.

NORRIS, J. M. AND BARKHAM, J. P. 1970. A comparison of some Cotswold beechwoods using multiple-discriminant analysis. J. Ecol., 58, 603-619.

PARSONS, P. A. 1983. The evolutionary biology of colonising species. Cambridge University Press, London.

POOSTCHI, I. AND MACDONALD, H. A. 1961. Inheritance of leaf colour in broadleaf birdsfoot trefoil. Crop Sci., 1 , 327-328.

ROBINSON, D. H. 1934. Birdsfoot trefoil in agriculture. Emp. J. Exp. Agric., 2, 274-283.

ROMEDER, J. M. 1978. Méthodes et programmes d'analyse discriminante, Dunod, Paris.

SALISBURY, E. J. 1961. Weeds and aliens. Collins New Naturalist, London.

SEANEY, R. R. AND hENSON, P. R. 1970. Birdsfoot trefoil. Adv. Agron., 22, 119-157.

SHEPPARD, P. M. 1951. A quantitative study of two populations of the moth Panaxia dominula (L.). Heredity, 5, 349-378.

SHEPPARD, P. M. AND COOK, L. M. 1962. The manifold effects of the medionigra gene in the moth Panaxia dominula and the maintenance of a polymorphism. Heredity, 17, 415-426.

SMALL, E., GRANT, W. F. AND CROMPTON, C. W. 1984. A taxonomic study of the Lotus corniculatus complex in Turkey. Canad. J. Bot., 62, 1044-1053.

STEBBINS, G. L. 1950. Variation and evolution in plants. Columbia University Press, New York.

TANTISEWIE, B., RUIJG ROK, H. W. L. AND HEGNAUER, R. 1969. Die verbreitung der blausäure bei den cormophyten 5 . Mitteilung: über cyanogene verbindungen bei den parietales und bei einigen weiteren sippen. Pharm. Weekblad, 104, 1341-1355.

WILliAMS, B. K. 1983. Some observations on the use of discriminant analysis in ecology. Ecology, 64, 1283-1291.

ZANDSTRA, I. I. AND GRANT, W. F. 1968. The biosystematics of the genus Lotus (Leguminosae) in Canada. I. Cytotaxonomy. Can. J. Bot., 46, 557-583. 